\title{
Field evaluation of a new third generation push-pull technology for control of striga weed, stemborers, and fall armyworm in western Kenya
}

\author{
Duncan Cheruiyot $^{1,2}\left(D\right.$, Frank Chidawanyika ${ }^{1,3}$, Charles A. O. Midega ${ }^{1}$, Jimmy O. Pittchar ${ }^{1}$, \\ John A. Pickett ${ }^{4}$ and Zeyaur R. Khan ${ }^{1, \star}$

\begin{abstract}
${ }^{1}$ International Centre of Insect Physiology and Ecology (icipe), P.O. Box 30772-00100, Nairobi, Kenya, ${ }^{2}$ Rwanda Institute for Conservation Agriculture (RICA), Bugesera, Rwanda, ${ }^{3}$ Department of Zoology and Entomology, University of the Free State, P.O. Box 339, Bloemfontein, 9300, Republic of South Africa and ${ }^{4}$ School of Chemistry, Cardiff University, Cardiff CF10 3AT, UK ${ }^{\star}$ Corresponding author. Email: zkhan@icipe.org
\end{abstract}

(Received 15 September 2021; revised 19 November 2021; accepted 03 December 2021; first published online 08 February 2022)

\begin{abstract}
Summary
Production of cereal crops in sub-Saharan Africa is threatened by parasitic striga weeds and attack by stemborers and the invasive fall armyworm (FAW), compounded by increasing hot and dry conditions. A climate-smart push-pull technology (PPT) significantly reduces effects of these biotic challenges. To improve further resilience of the system to climate change, more adapted and suitable companion plants were identified and integrated in a new version of PPT, termed 'third generation PPT'. Our study evaluates field performance and farmer opinions of this new version in comparison with the earlier version, climatesmart PPT, and farmers' own practices of growing maize in controlling stemborers, FAW, and striga weeds. Trials were conducted across five locations in western Kenya for two cropping seasons in the year 2019 following a one-farm one-replicate completely randomized design. We assessed infestation on striga, stemborers, and FAW, and yield performance of the three cropping systems. We also sought the opinions of the hosting farmers through semi-structured questionnaires that were administered through individual interviews. Both PPT plots recorded significantly $(P<0.05)$ lower striga count, FAW, and stemborer damage, and higher grain yield than in plots that followed farmers' own practices. There was no statistically significant difference between the two PPT plots except for stemborer damage for which the third generation PPT recorded higher damage than the climate-smart PPT. However, farmers preferred the third generation PPT for important traits possessed by its companion plants which their counterparts in climate-smart PPT are deficient. The cultivar Xaraes was rated as 'very good' for resistance to spider mites, biomass yield, and drought tolerance while Desmodium incanum was rated 'very good' for seed production and drought tolerance. The third generation PPT is based on companion crops that are more resilient to hot and dry conditions which are increasing rapidly in prevalence with climate change. This version therefore presents a better option to upscale the technology and meet different needs of farmers especially in arid and semi-arid conditions.
\end{abstract}

Keywords: Cereal pests; Climate-smart agriculture; Companion planting; Small-holder farmers; Western Kenya

\section{Introduction}

Maize (Zea mays L.) and sorghum (Sorghum bicolor L. Moench) are the most important cereal crops in sub-Saharan Africa (SSA). Maize accounts for $40 \%$ of the cereal production in the region, where more than $80 \%$ is used as food (FAOSTAT, 2016). The demand for maize in the region is

(C) The Author(s), 2022. Published by Cambridge University Press. This is an Open Access article, distributed under the terms of the Creative Commons Attribution-NonCommercial licence (http://creativecommons.org/licenses/by-nc/4.0/), which permits non-commercial re-use, distribution, and reproduction in any medium, provided the original article is properly cited. The written permission of Cambridge University Press must be obtained prior to any commercial use. 
projected to triple by 2050 due to rapid population growth (Ekpa et al., 2018). However, maize production is threatened mainly by insect pests, weeds, degraded soils, and increasing hot and dry weather conditions associated with climate change (Ziska et al., 2011). Sorghum is the second most important cereal grain in Africa after maize, Africa accounts for approximately $42 \%$ of global sorghum production (Hariprasanna and Rakshit, 2016). Importance of sorghum to food security in Africa is largely due to its resistance to drought (Jordan and Sullivan, 1982). According to the Intergovernmental Panel on Climate Change report 2019, yields of some crops (e.g., maize and wheat) in many lower-latitude regions with dryland conditions, a characteristic of many parts of Africa, are negatively affected (Mbow et al., 2019). This threatens productivity of rain-fed agriculture, food security, and livelihoods of the majority low-income consumers in the region.

Insect pests, particularly lepidopterous stemborers Chilo partellus (Swinhoe) (Lepidoptera: Crambidae) and Busseola fusca (Fuller) (Lepidoptera: Noctuidae) and fall armyworm Spodoptera frugiperda (J.E. Smith) (Lepidoptera: Noctuidae) (FAW), severely impact smallholder cereal production in SSA (Khan et al., 2010; Midega et al., 2010). Yield losses vary with locations and phenological stage of the crop. For instance, up to $100 \%$ stalk damage in maize and up to $80 \%$ grain yield loss in sorghum by C. partellus were observed in Kenya on 20-day-old crops (Kfir et al., 2002). Farmers in low-potential areas of Kenya estimated losses in maize grain yield at $15-21 \%$ (De Groote, 2002). The FAW recently invaded SSA causing extensive damage especially to maize and to a lesser degree to sorghum and other poaceous crops including millet, fonio, rice, and sugarcane (Goergen et al., 2016). The pest severely impacts maize production, for instance, farmer perception studies estimated maize grain yield losses of 34\%, more than 1 million tons of maize in Kenya alone (De Groote et al., 2020) while field scouting estimated yield losses at $11.6 \%$ in Eastern Zimbabwe (Baudron et al., 2019). The parasitic striga weed Striga hermonthica (Del.) Benth. (Lamiales: Scrophulariaceae) is another significant problem to cereal crop production in SSA (Stewart et al., 1991). It attaches to the roots in response to chemical signals from the host plant and obtains carbon assimilates, water, nutrients, and amino acids from its host, thereby deriving the host of its nutritional requirements and resulting in poor growth and yield (Hooper et al., 2009; Pageau et al., 2003). Degraded environments, poor soil fertility, and climate change effects resulting in up to $100 \%$ grain yield aggravate effects of striga. Maize grain yield losses are estimated to be more than US\$7 billion in SSA annually (Berner et al., 1995).

Scientists at the International Centre of Insect Physiology and Ecology (icipe), in Kenya in close collaboration with Rothamsted Research, in the United Kingdom, and several national partners developed the push-pull technology (PPT). The technology controls stemborers, FAW, and striga weed while improving soil fertility (Cook et al., 2006; Khan et al., 2001; Zeyaur R. Khan et al., 2008a; Midega et al., 2018, 2015b). The technology involves trapping the pest on highly attractive trap plants (pull) while driving them away from the main crop using repellent intercrops (push). The first generation of PPT consisted of silverleaf desmodium Desmodium uncinatum (Jacq.) DC (Fabales: Fabaceae) (push) and Napier grass Pennisetum purpureum (Schumach) (Poales: Poaceae) (pull) which were selected during 1995-1998 for pest management across a range of agro-ecologies (Figure 1) (Cook et al., 2006; Khan et al., 2000, 2010). The trap plant releases semiochemicals that attract stemborers moths while volatile chemicals from the 'push' crop further enhance effectiveness of the trap crop by repelling moths away from the main crop (Birkett et al., 2006; Cook et al., 2006; Khan et al., 2000; Pickett et al., 2014; Pickett and Khan, 2016). A total of 41 volatile compounds identified from the wild hosts, Napier grass and Hyparrhenia tamba (Poales: Poaceae) and the cultivated hosts maize and sorghum Sorghum bicolor (Poales: Poaceae) elicited an electrophysiological response from one or both of stemborer species, B. fusca and C. partellus (Birkett et al., 2006). Further, the wild hosts produced higher levels of physiologically active green leaf volatiles, hexanal, (E)-2-hexenal, $(Z)$-3-hexen-1-ol, $(Z)$-3-hexenyl acetate, and indole compared with either of the cultivated hosts (Birkett et al., 2006). A 95\% increase in the green leaf volatiles (hexanal, (E)-2-hexenal, $(Z)$-3-hexen-1-ol, and (Z)-3-hexen-1yl acetate was observed at the onset of scotophase, the light-dark transition period (Chamberlain et al., 2006). This is 


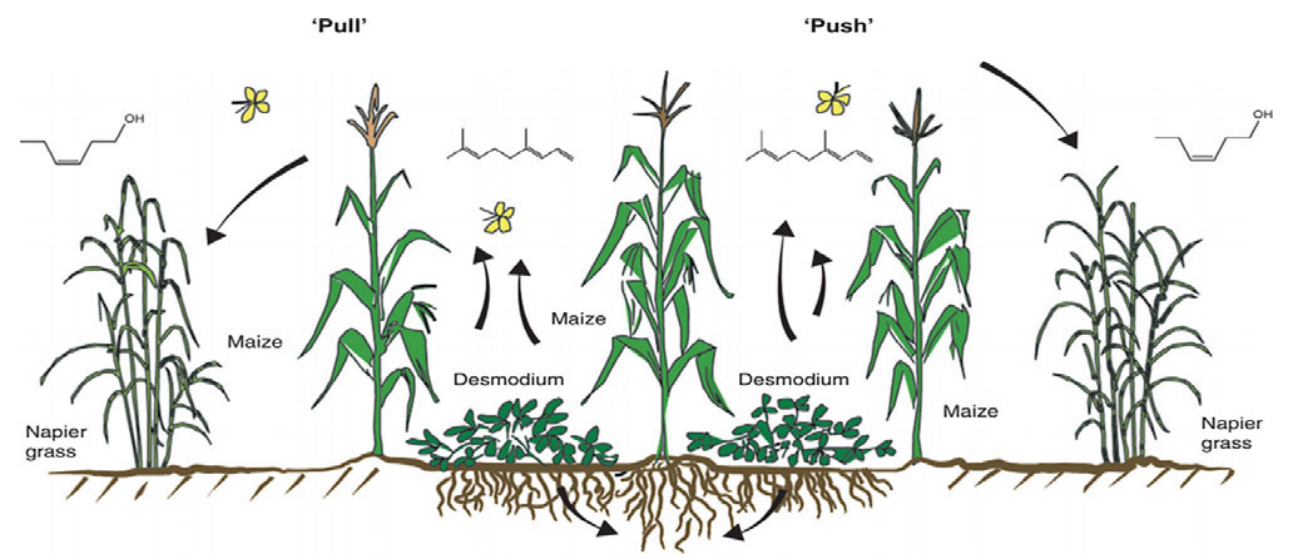

Figure 1. Illustration of a first generation push-pull. Source: Pickett et al. (2014).

the time when the moths actively seek host plants for egg laying (Päts, 1991). Napier grass varieties that attract oviposition by stemborer moths were identified in previous studies (Khan et al., 2007; Van Den Berg, 2006) and some have been used as trap plants in PPT. However, not all the Napier grass varieties are preferred for oviposition (Calatayud et al., 2008; Khan et al., 2007). On the other hand, desmodium emits the repellent (E)-4,8-dimethyl-1,3,7-nonatriene and (E)-ocimene in enhanced quantities, which also attract the natural enemies (Khan et al., 2000). The nonatriene in particular has been implicated as an 'SOS' signal recruiting predators and parasites (Khan et al., 1997; Mutyambai et al., 2016; Turlings et al., 1995). Indeed, there is increased abundance, diversity, and activity of predatory arthropods in PPT which further improves its effectiveness in pest management (Midega et al., 2015a). Furthermore, a recent study observed soil from desmodium and maize intercrop field induced soil-mediated alterations in plant secondary metabolism which were associated with reduced herbivory by C. partelllus larvae (Mutyambai et al., 2019).

The mechanism of striga weed control in the system involves production of chemical substances produced by desmodium roots that cause suicidal germination and inhibit radical growth of the weed (Hooper et al., 2010; Khan et al., 2016, 2002; Tsanuo et al., 2003). Soil health is significantly improved in PPT owing to the capacity of desmodium to fix approximately $154 \mathrm{~kg}$ of nitrogen per acre per year under optimum conditions (Whitney, 1966). Further, the companion plants provide high value animal fodder, facilitating milk production and diversifying farmers' sources of income.

The increasingly arid conditions resulting from climate change is a major threat to sustainability and expansion of the original PPT into drier agro-ecologies where striga is rapidly spreading. Efforts to adapt PPT to climate change conditions and thereby ensure sustainable cereal production led to identification of drought tolerant and the consequently suitable greenleaf desmodium, D. intortum (Mill.) Urb. (push) and Brachiaria brizantha cv Mulato II (Poales: Poaceae) (pull) companion crops as components of a second generation PPT referred to as 'climate-smart PPT' (Khan et al., 2018; Midega et al., 2015b). Besides its tolerance to drought, Mulato II supports oviposition by stemborers although less preferred to maize and is preferred as livestock fodder (Cheruiyot et al., 2018b; Chidawanyika et al., 2014; Midega et al., 2011). D. intortum on the other hand has similar effects on striga as that of D. uncinatum and is also considered by farmers as an excellent fodder (Midega et al., 2010; Murage et al., 2015).

Although the climate-smart PPT was initially developed for control of lepidopterous stemborers and striga weed, a recent study indicates that it is also highly effective in controlling FAW, reducing plant damage caused by the pest by up to $86.7 \%$ (Khan et al., 2018). Farmers also rated the technology as superior to other methods in reducing FAW infestation and plant damage rating 


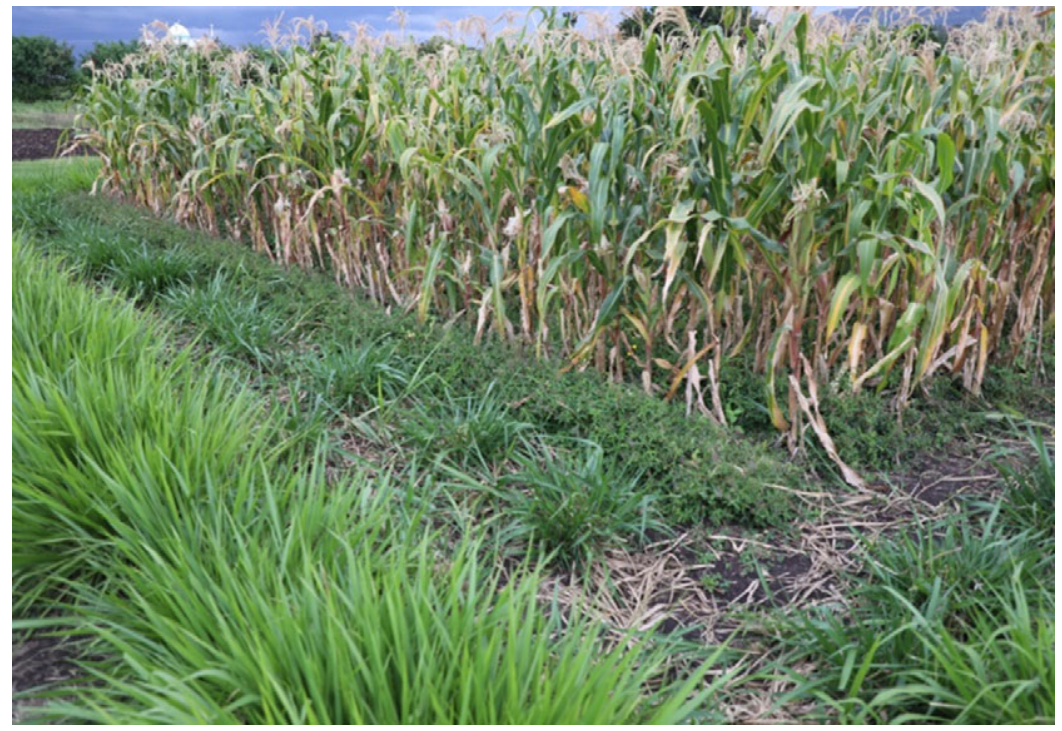

Figure 2. Third generation push-pull (3G-PPT) field. Desmodium incanum is intercropped with maize as a 'push' crop and surrounded by Brachiaria brizantha cv Xaraes as a trap crop.

(Midega et al., 2018). Not long after introduction of climate-smart PPT, the invasive spider mites Oligonychus trichardti Meyer (Acari: Tetranychidae) emerged as a new threat causing foliar damage of up to $80-100 \%$ in Mulato II especially in hot and dry weather regimes that characterize most parts of SSA (Maass et al., 2015). In a recent study, leaf damage caused by the mites was negatively correlated with chlorophyll content and biomass yield of brachiaria grasses, demonstrating the importance of spider mites in growth and development of Mulato II and generally its effectiveness in pest management strategies (Cheruiyot et al., 2018a). The other problem of climate-smart PPT as reported by farmers in eastern Africa is that D. intortum does not produce flower and seeds near the equator. This presented new challenges to the system and a need to identify alternate resistant genotypes. Large-scale dissemination of PPT depends on availability of seeds of companion crops to farmers. Seeds of Mulato II are commercially available while imported seeds of $D$. intortum are expensive and their availability is limited, presenting another challenge in up-take of the technology (icipe, 2019).

To address the challenges affecting sustainability and large-scale dissemination of climatesmart PPT, more adapted and suitable alternative brachiaria and desmodium varieties have been identified (Midega et al., 2018). D. incanum was selected for its tolerance to longer drought stress conditions (Midega et al., 2017). D. incanum also produced flowers and seeds in the regions where $D$. intortum did not flower. Allelochemicals produced in the root exudate of $D$. incanum also effectively inhibited striga development in both pot and field conditions (Hooper et al., 2015). B. brizantha $\mathrm{cv}$ Xaraes alternatively combines moderate resistance to spider mites, adaptability across different agro-ecologies, and high biomass yield in both field and simulated drought conditions (Cheruiyot et al., 2018a, 2018c). It also attracts oviposition by the pest while being detrimental to its larvae (Cheruiyot et al., 2018b). Farmers rated Xaraes as superior in biomass yield moderately resistant to spider mites, an important pest of brachiaria in the region (Cheruiyot et al., 2020). These results demonstrate potential of the newly identified companion in improving resilience of PPT and sustaining cereal production that depends on the system. Thus, the new companion plants, namely D. incanum (push) and Xaraes (pull) (Figure 2), were used to develop a new third generation PPT. In the current study, effectiveness of the new version in controlling stemborers, 
Table 1. Average rainfall, maximum temperature, minimum temperature, and relative humidity during the period of study in 2019, across five locations in western Kenya

\begin{tabular}{|c|c|c|c|c|c|}
\hline \multirow[b]{2}{*}{ Location } & \multirow[b]{2}{*}{ Season } & \multirow[b]{2}{*}{ Rainfall (mm) } & \multicolumn{2}{|c|}{ Temperature $\left({ }^{\circ} \mathrm{C}\right)$} & \multirow[b]{2}{*}{ Relative humidity (\%) } \\
\hline & & & Max & Min & \\
\hline \multirow[t]{2}{*}{ Bondo } & Long rains & 443.8 & 25.5 & 17.5 & 78.3 \\
\hline & Short rains & 354.8 & 26.5 & 17.3 & 75.5 \\
\hline \multirow[t]{2}{*}{ Siaya } & Long rains & 345.5 & 27.8 & 18.3 & 77.3 \\
\hline & Short rains & 345.8 & 27.0 & 18.5 & 75.8 \\
\hline \multirow[t]{2}{*}{ Vihiga } & Long rains & 234.8 & 26.0 & 15.2 & 77.8 \\
\hline & Short rains & 438.0 & 25.7 & 15.0 & 76.0 \\
\hline \multirow[t]{2}{*}{ Suba } & Long rains & 237.1 & 25.3 & 16.0 & 78.5 \\
\hline & Short rains & 251.3 & 24.5 & 16.3 & 78.8 \\
\hline \multirow[t]{2}{*}{ Kisumu } & Long rains & 345.5 & 27.8 & 18.3 & 77.3 \\
\hline & Short rains & 345.5 & 27.0 & 18.5 & 75.8 \\
\hline
\end{tabular}

FAW, and striga weed is evaluated in comparison with the earlier version of climate-smart PPT, common farmer practices (FPs).

\section{Materials and Methods \\ Study sites}

Trials were conducted during long rains and short rains cropping seasons in 2019 across five locations in western Kenya. The locations were Siaya $\left(0^{\circ} 00^{\prime}-0^{\circ} 11^{\prime} \mathrm{N}, 34^{\circ} 16^{\prime}-34^{\circ} 21^{\prime} \mathrm{E}\right)$, Vihiga $\left(0^{\circ} 00^{\prime}-0^{\circ}\right.$ $\left.05^{\prime} \mathrm{N}, 34^{\circ} 30^{\prime}-34^{\circ} 35^{\prime} \mathrm{E}\right)$, Kisumu $\left(0^{\circ} 00^{\prime}-0^{\circ} 05^{\prime} \mathrm{S}, 34^{\circ} 35^{\prime}-34^{\circ} 41^{\prime} \mathrm{E}\right)$, Bondo $\left(0^{\circ} 00^{\prime}-0^{\circ} 05^{\prime} \mathrm{S}, 34^{\circ} 35^{\prime}-34^{\circ}\right.$ $\left.41^{\prime} \mathrm{E}\right)$, and Suba $\left(0^{\circ} 25^{\prime}-0^{\circ} 30^{\prime} \mathrm{S}, 34^{\circ} 12^{\prime}-34^{\circ} 56^{\prime} \mathrm{E}\right)$ (Fig. S1). These maize and sorghum-growing regions experience extended periods of drought, receiving an average of 600-1200 mm of rainfall per annum and mean annual temperature of $27^{\circ} \mathrm{C}$. The long rainy season begins in April to July and the short rainy season from October to January. The rainfall, temperature, and relative humidity for the period study in each location are presented in Table 1 . The cereal crops are severely impacted by the lepidopterous stemborers $C$. partellus and B. fusca, attacks by the invasive FAW and striga weed (Khan et al., 2008a, 2001; Midega et al., 2018) in the region, and farmers have adopted PPT for management of these pests (Midega et al., 2015b).

\section{Experimental setup}

We conducted on-farm trials in five locations (Siaya, Vihiga, Kisumu, Bondo, and Suba). Trials were replicated five times in different farmers' fields (farms) in each location except in Vihiga and Siaya where four replicates (farms) were done in each of the two locations. Farms (replicates) were randomly selected with the help of local extension officers, and a semi-structured questionnaire was used to determine their willingness to participate in a study to evaluate efficiency of two variants of PPT in comparison with their own practices. Plot size and layout followed the methods as described (Midega et al., 2015b). The three treatments, that is, climate-smart push-pull technology (CS-PPT), the third generation push-pull technology (3G-PPT), and FP (maize monocrop), were established in plots of equal sizes in each farm in a one-farm one-replicate randomized design and were spaced at 10-25 m from each other. This gave five replicates in each location except in Vihiga and Siaya where we had four farms (replicates) in each of the two locations. The plot sizes, however, varied in size from farm to farm (ranging from $18 \mathrm{~m}$ by $18 \mathrm{~m}$ to $40 \mathrm{~m}$ by $40 \mathrm{~m}$ ). Farmers in the region prefer maize mono cropping; this was done in all the FP plots in the current study. Planting was done at the onset of each season. Maize in all the plots was planted at plant-plant and row-row spacing of 30 and $75 \mathrm{~cm}$, respectively. Desmodium was planted in between rows of maize through a drilling system. Maize/desmodium intercrop was separated by $1 \mathrm{~m}$ wide alleyway 
from a border crop consisting of four rows of B. brizantha cv Mulato II and B. brizantha cv Xaraes for climate-smart PPT and third generation PPT, respectively. Brachiaria was planted at plantplant and row-row spacing of $50 \mathrm{~cm}$. Planting in the control plot followed the same procedure, but without desmodium and brachiaria companion crops. The FP plots followed own practices of the farmers who hosted the trials, for example, whether or not to include intercrops of their choices. These farmers mostly practiced maize monocrop. Diammonium phosphate was applied to all the crops as basal fertilizer at a rate of $60 \mathrm{~kg} / \mathrm{ha}$ and nitrogen as a top dresser 4 weeks after emergence of sorghum in the form of calcium ammonium nitrate, at a rate of $60 \mathrm{~kg} / \mathrm{ha}$. Brachiaria and desmodium are perennials; thus, they were planted once and cut back at the onset of subsequent season. Plots were kept weed free by hoe and hand weeding except for striga throughout the growing season.

\section{Data collection}

Infestation by striga and stemborers was assessed following procedures previously described (Khan et al., 2008a) where 100 maize plants were randomly selected in each of the plot and tagged for subsequent observations. Three outer rows were excluded from observations (buffer rows) to minimize border effects from the adjacent treatments. At 10 weeks after emergence of maize/ sorghum, emerged striga plants were counted within a radius of $15 \mathrm{~cm}$ of each of the tagged plants.

At the same time, plants with characteristic foliar damage caused by stemborer larval feeding were counted and expressed as the percentage of plants damaged. Stemborer feeds on foliar of the plant causing 'window-paned' and 'pin-holed' leaves and/or dead-hearts (Kfir et al., 2002). The FAW infestation was assessed following modifications of procedures previously described (Midega et al., 2018). At 10 weeks after planting, damage was assessed by examining the young leaves, leaf whorls, tassels of 100 randomly selected plants for visible larval damage, and the data expressed as percentage of plants damaged. All plants in each plot were harvested at physiological maturity and grain yields converted into tons per hectare at $12 \%$ moisture content.

Opinions of the farmers who hosted the trials in the study (23 farmers) were assessed through semi-structured questionnaires that were administered through individual interviews. The questionnaires were pre-tested before the interviews. The questionnaire assessed farmers' socioeconomic characteristics (e.g., age, gender, and education) and farm characteristics (farm tenure system). We sought farmers' comparison of the two PPT variants against their own practice in controlling stemborers, FAW, and striga weed. They rated Mulato II and Xaraes trap plants by traits of their interest including resistance to spider mites, forage quantity and quality, and drought tolerance. The two desmodium varieties were compared based on their ability to flowering and set seed, forage quantity, and quality and drought tolerance. Lastly, we determined their willingness to continue practicing and/or expand third generation PPT and whether other farmers in the area were interested in taking up the PPT.

\section{Data analysis}

Data were analyzed using linear mixed model fitted by REML using lmer function from the $1 m e 4$ package in R program v.4.0.2. (R Core Team, 2020). Cropping system, location, and their interactions were treated as fixed effects while replicates were treated as random effects, with each season analyzed separately. Prior to analysis, data on striga count were $\log 10(\mathrm{x}+1)$ transformed while data on proportions of plants damaged by stemborers and FAW were subjected to arcsine transformation to normalize the data and stabilize the variance. Means were compared using least significant differences and non-transformed means presented in the tables. Data on farmers' perceptions were subjected to descriptive statistics using statistical package for SPSS version 17 software (IBM Corporation, Armonk, NY, USA). Non-transformed data are presented in the results section. 
Table 2. Analysis of variance for tested effects and their interactions for striga count, stemborer and fall armyworm (FAW) damage, and maize grain yield for different cropping systems evaluated across five locations during two seasons in 2019

\begin{tabular}{|c|c|c|c|c|}
\hline Source of variation & Striga count & Stemborer damage & Fall armyworm damage & Grain yield \\
\hline \multicolumn{5}{|l|}{ Long rains 2019} \\
\hline Location & 0.055 & $<0.001$ & $<0.001$ & 0.000225 \\
\hline Cropping system & $<0.001$ & $<0.001$ & $<0.001$ & 0.000001 \\
\hline Farmer & 0.839 & 0.610 & 0.569 & 0.616578 \\
\hline Location $\times$ cropping system & 0.138 & 0.042 & $<0.001$ & 0.005178 \\
\hline Location $\times$ farmer & 0.738 & 0.216 & 0.022 & 0.000829 \\
\hline $\begin{array}{l}\text { Cropping system } \times \text { farmer } \\
\text { Short rains } 2019\end{array}$ & 0.935 & 0.329 & 0.662 & 0.627338 \\
\hline Location & $<0.001$ & $<0.001$ & 0.045 & $<0.001$ \\
\hline Cropping system & $<0.001$ & $<0.001$ & $<0.001$ & 0.042 \\
\hline Farmer & 0.621 & 0.770 & 0.814 & 0.402 \\
\hline Location $\times$ cropping system & 0.002 & 0.018 & $<0.001$ & 0.008 \\
\hline Location $\times$ farmer & 0.359 & 0.071 & $<0.001$ & 0.036 \\
\hline Cropping system $\times$ farmer & 0.074 & 0.208 & 0.264 & 0.996 \\
\hline
\end{tabular}

Values in bold are significant $(P<0.05)$.

\section{Results}

\section{Field performance of different cropping systems}

Results of the long rains 2019 (LR2019) revealed significant effects of the cropping system for striga count $\left(F_{2,6}=134 ; P<0.001\right)$, stemborer damage $\left(F_{2,7}=31.54 ; P<0.001\right)$, FAW damage $\left(F_{2,7}=134 ; P<0.001\right)$, and grain yield $\left(F_{2,7}=217 ; P<0.001\right)$ (Table 2$)$. Effects of location were significant for stemborer damage $\left(F_{4,14}=17.59 ; P<0.001\right)$, FAW damage $\left(F_{4,14}=11.74\right.$; $P<0.001)$, and grain yield $\left(F_{4,14}=11.46 ; P<0.001\right)$ while non-significant for striga count suggesting that environmental conditions also play a role in efficiency of PPT in controlling stemborer, FAW, and yield performance of maize. Replications (farms per location) were nonsignificant. Further, location $\times$ cropping system interactions were significant for stemborer damage $\left(F_{8,29}=2.38 ; P<0.05\right)$, FAW damage $\left(F_{8,29}=11.23 ; P<0.001\right)$, and grain yield $\left(F_{8,29}=3.60 ; P<0.05\right)$ but not significant for striga count. During the short rains 2019, significant differences were detected in location for striga count $\left(F_{4,12}=9.44 ; P<0.001\right)$, stemborer damage $\left(F_{4,12}=16.47 ; P<0.001\right)$, FAW damage $\left(F_{4,12}=3.36 ; P=0.04\right)$, and yield $\left(F_{4,12}=18.01\right.$; $P<0.001)$. Similarly, effects of cropping system were significant, that is, striga count $\left(F_{2,7}=72.81 ; \quad P<0.001\right)$, stemborer damage $\left(F_{2,7}=48.78 ; \quad P<0.001\right)$, FAW damage $\left(F_{2,7}=52.99 ; P<0.001\right)$, and yield $\left(F_{2,7}=93.58 ; P=0.04\right)$ (Table 2$)$. Analysis also detected significant interactions of location $\times$ cropping system for striga count $\left(F_{8,26}=4.17 ; P<0.001\right)$, stemborer damage $\left(F_{8,26}=2.90 ; P<0.001\right)$, FAW damage $\left(F_{8,26}=9.46 ; P<0.001\right)$, and yield $\left(F_{8,26}=3.48 ; P=0.008\right)$ while location $\times$ farmer interactions were only significant for FAW damage $\left(F_{12,24}=4.39 ; P<0.001\right)$ and yield $\left(F_{12,24}=2.353 ; P=0.035\right)$.

Means of the parameters in each cropping season in 2019 are presented in Figure 3. Striga weed count, stemborer damage, and FAW damage were significantly high in FP plots compared to both CS-PPT and 3G-PPT. The FP plots recorded the lowest grain yield. Values for these parameters were statistically similar in each season for the CS-PPT and FP-PPT except for striga count during the long rains where striga count in 3G-PPT was higher than in CS-PPT $(P<0.05)$. Results per location revealed that FP plots recorded significantly $(P<0.05)$ higher striga weed infestation than CS-PPT and 3G-PPT across all the locations and seasons except in Bondo (long rains) where FP did not differ significantly with 3G-PPT (179.4 and 127.2, respectively) (Table 3). Stemborer damage followed this trend with exception of Siaya (long rains) where means in all the plots differ significantly from each other with FP recording the highest 

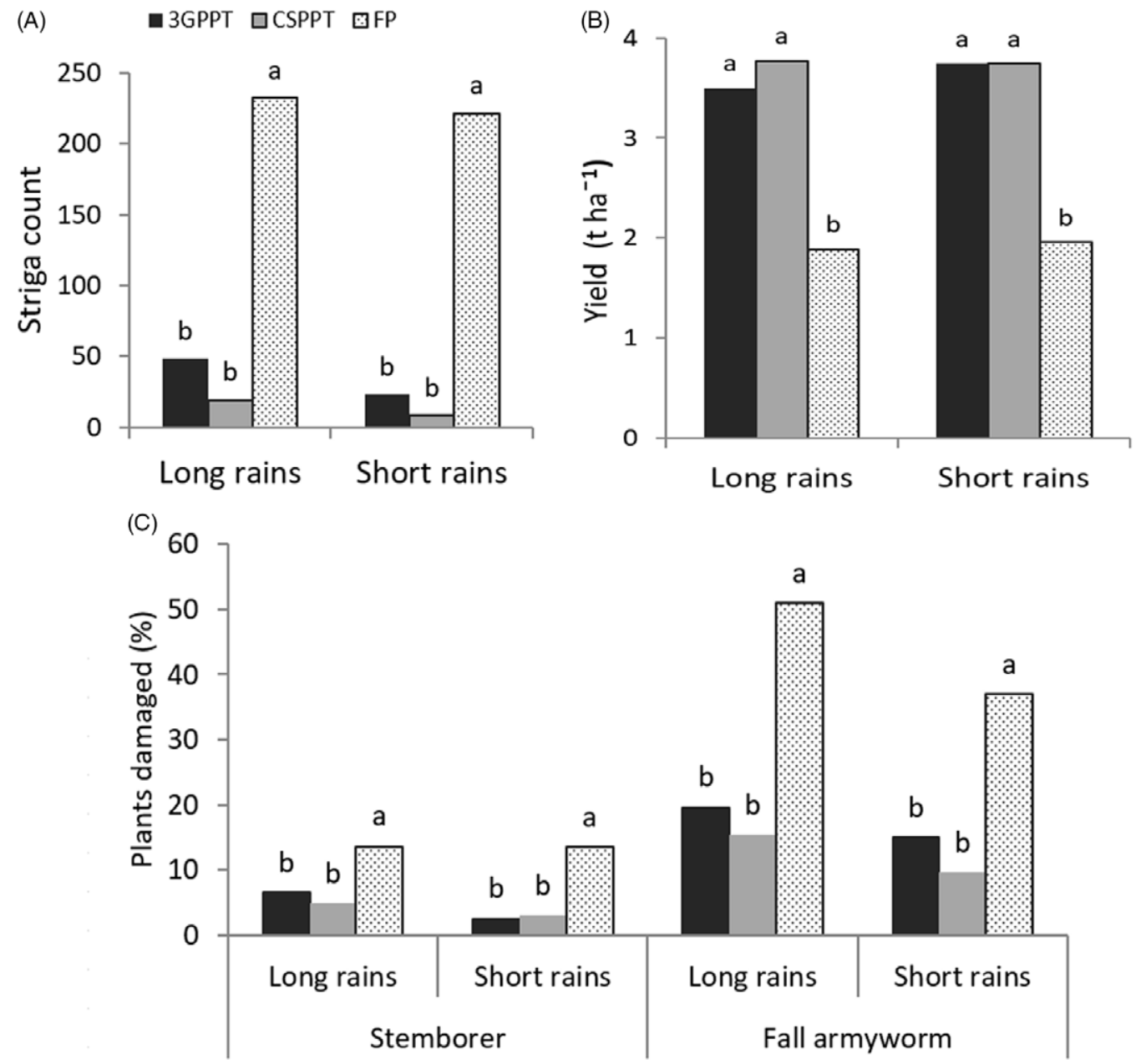

Figure 3. Means for striga count per 100 maize plants (A), maize grain yield ( $\left.\mathrm{tha}^{-1}\right)(\mathrm{B})$, and percentage of stemborer and FAW damaged plants (C) in climate-smart push-pull technology (CS-PPT), third generation push-pull technology (3G-PPT) and farmer practice (FP) plots for two cropping seasons in 2019 across five locations in western Kenya.

number of plants damaged (11.3\%) and CS-PPT recording the lowest $(0.8 \%)$. Same trend was observed in Bondo during the short rains season, FP plots recorded the highest stemborer damage (25.8\%), and CS-PPT being the least damaged (5.6\%). In Kisumu, however, during the long rains season, there was no significant difference in damage caused by the stemborers in the three plots. Concerning plants damaged by the FAW, the three cropping systems differed significantly $(P<0.05)$ with FP plots being the most damaged and CS-PPT the least damaged in Bondo (longs rains), Siaya and Suba (short rains). In Bondo (short rains), there was no significance in FAW damage in the three cropping systems. For the rest of locations in each season, FP plots recorded significantly higher damage while $3 \mathrm{G}-\mathrm{PPT}$ and CS-PPT were the same statistically. Lastly, FP plots recorded significantly $(P<0.05)$ the lowest maize grain yield in all locations and seasons. There were instances of statistical similarities and interchanges between CSPPT and 3G-PPT. Specifically, in Suba (long and short rains seasons), CS-PPT recorded significantly higher grain yield than 3G-PPT, while 3G-PPT yielded higher in Siaya and Bondo during the short rains season (Table 3). 
Table 3. Mean ( \pm SEM) number of striga, stemborer and FAW damage, and maize grain yield for different cropping systems in five locations in western Kenya for two seasons in 2019

\begin{tabular}{|c|c|c|c|c|c|c|}
\hline & Location & Farming type & Striga & Stemborer damage (\%) & FAW damage (\%) & Yield (t ha ${ }^{-1}$ ) \\
\hline \multirow[t]{15}{*}{ Long rains 2019} & \multirow[t]{3}{*}{ Bondo } & 3G-PPT & $127.2(14.6) a$ & 16.6 (1.3)ab & $26.2(2.3) b$ & $5.2(0.2) a$ \\
\hline & & CS-PPT & $31.8(12.4) \mathrm{b}$ & $12.6(2.8) \mathrm{b}$ & $14.6(2.5) \mathrm{c}$ & $4.6(0.2) a$ \\
\hline & & $\mathrm{FP}$ & $179.4(19.8) \mathrm{a}$ & $20.6(1.1) a$ & $35.0(3.8) a$ & $2.8(0.1) b$ \\
\hline & \multirow[t]{3}{*}{ Siaya } & 3G-PPT & $16.8(3.9) b$ & $4.5(1.2) d$ & $29.3(10.5) b$ & $3.8(0.5) a$ \\
\hline & & CS-PPT & $27.0(6.5) b$ & $0.8(0.8) \mathrm{c}$ & $30.5(16.8) b$ & $3.5(0.6) a$ \\
\hline & & $\mathrm{FP}$ & $286.0(59.7) a$ & $11.3(2.2) a$ & $99.5(0.3) a$ & $2.2(0.4) b$ \\
\hline & \multirow[t]{3}{*}{ Kisumu } & 3G-PPT & $60.4(22.8) b$ & $2.8(1.5) a$ & $6.0(1.1) b$ & $3.8(0.3) \mathrm{a}$ \\
\hline & & CS-PPT & $16.6(5.8) b$ & $2.8(0.9) a$ & $5.4(1.8) b$ & $3.5(0.5) a$ \\
\hline & & $\mathrm{FP}$ & $286(44.6) a$ & $6.4(1.0) a$ & $44.0(2.3) a$ & $1.6(0.0) b$ \\
\hline & \multirow[t]{3}{*}{ Suba } & 3G-PPT & $19.8(3.4) \mathrm{b}$ & $4.6(0.4) b$ & $19.0(1.2) \mathrm{b}$ & $3.1(0.1) b$ \\
\hline & & CS-PPT & $15.0(2.7) \mathrm{b}$ & $4.6(1.2) \mathrm{b}$ & $13.0(2.0) \mathrm{b}$ & $3.6(0.1) a$ \\
\hline & & $\mathrm{FP}$ & $146.8(19.8) a$ & $19.4(1.3) a$ & $35.0(2.5) a$ & $1.6(0.1) c$ \\
\hline & \multirow[t]{3}{*}{ Vihiga } & 3G-PPT & $18.3(6.2) b$ & $3.8(1.7) \mathrm{b}$ & $17.5(4.3) b$ & $3.3(0.2) a$ \\
\hline & & CS-PPT & $6.3(2.5) b$ & $3.5(1.3) b$ & $13.3(2.0) b$ & $3.7(0.3) a$ \\
\hline & & $\mathrm{FP}$ & $262.5(85.0) a$ & $10.3(1.3) a$ & 41.5 (3.5)a & $1.3(0.0) \mathrm{b}$ \\
\hline \multirow[t]{15}{*}{ Short rains 2019} & \multirow[t]{3}{*}{ Bondo } & 3G-PPT & $37.2(7.0) b$ & $13.4(3.5) \mathrm{b}$ & $13.4(3.54) a$ & $6.2(0.4) a$ \\
\hline & & CS-PPT & $16.8(6.9) b$ & $5.6(5.1) c$ & $10.8(5.7) a$ & $5.1(0.2) b$ \\
\hline & & FP & $207.0(21.5) a$ & $25.8(7.5) a$ & $25.0(7.5) a$ & $3.0(0.3) c$ \\
\hline & \multirow[t]{3}{*}{ Siaya } & 3G-PPT & $2.3(1.3) \mathrm{b}$ & $3.3(1.1) \mathrm{b}$ & $17.0(4.4) \mathrm{b}$ & $4.9(0.3) a$ \\
\hline & & CS-PPT & $2.3(1.3) b$ & $1.3(0.8) b$ & $2.0(2.0) c$ & $3.8(0.2) b$ \\
\hline & & $\mathrm{FP}$ & $295.3(51.6) a$ & $8.5(0.6) a$ & $69.0(5.7) \mathrm{b}$ & $2.6(0.4) \mathrm{c}$ \\
\hline & \multirow[t]{3}{*}{ Suba } & 3G-PPT & $10.8(1.0) \mathrm{b}$ & $4.4(0.5) b$ & $22.8(1.0) \mathrm{b}$ & $3.1(0.2) b$ \\
\hline & & CS-PPT & $19.2(1.0) b$ & $5.8(0.4) b$ & $18.2(1.4) \mathrm{c}$ & $3.6(0.1) a$ \\
\hline & & $\mathrm{FP}$ & $250.6(37.2) a$ & $21.4(1.3) a$ & $39.2(1.1) a$ & $1.3(0.0) \mathrm{c}$ \\
\hline & \multirow[t]{3}{*}{ Kisumu } & 3G-PPT & 4.3 (2.3)b & $2.0(1.0) b$ & $3.5(1.1) \mathrm{b}$ & $4.0(0.2) a$ \\
\hline & & CS-PPT & $0.8(0.7) \mathrm{b}$ & $0.5(0.4) b$ & $3.5(0.9) b$ & $3.9(0.2) a$ \\
\hline & & $\mathrm{FP}$ & $171.0(15.7)^{‘} \mathrm{a}$ & $6.8(0.9) a$ & $22.0(2.5) a$ & $2.2(0.1) \mathrm{b}$ \\
\hline & \multirow[t]{3}{*}{ Vihiga } & 3G-PPT & $11.0(6.0) \mathrm{b}$ & $1.3(0.3) b$ & $18.3(4.4) \mathrm{b}$ & $4.2(0.3) a$ \\
\hline & & CS-PPT & $4.3(2.1) \mathrm{b}$ & $1.7(0.9) b$ & $13.3(3.2) b$ & $4.2(0.2) a$ \\
\hline & & $\mathrm{FP}$ & $183(3.8) a$ & $5.3(0.9) a$ & $30.0(1.7) a$ & $2.1(0.1) b$ \\
\hline
\end{tabular}

Means within columns followed by the same letter do not differ significantly at $P<0.05$ (LSD).

CS-PPT, climate-smart push-pull technology; 3G-PPT, third generation push-pull technology; FP, farmer practice; FAW, fall armyworm.

\section{Farmers' opinion on benefits of different cropping systems}

Socio-demographics of farmers hosting on-farm trials were determined (Table S1). Majority (36\%) of the respondents were aged between 51 and 60 years, while the youth (18-30 years) represented the minority (5\%). The farmers mostly attained secondary education $(48 \%)$ and a few $(10 \%)$ attained tertiary education (10\%). Majority of the farmers $(59 \%)$ had practiced the CS-PPT for over 5 years while $24 \%$ had practiced it for 3-4 years and therefore their opinions on different farming practices tested are considered to be well founded. After trying 3G-PPT for only two seasons, $86 \%$ of these farmers were eager to continue practicing this version of PPT. They cited reasons such as drought tolerance by the companion plants (20\%), good biomass yield by Xaraes $(17 \%)$, and FAW reduction by the system (15\%). Those who were not willing to continue (14\%) stated the main reason as being low biomass yield by D. incanum. On their intentions to expand the area of land under 3G-PPT, $72 \%$ were willing, while $20 \%$ were not. Those who were not willing were mainly limited by availability of farming land (15\%) and lack of seeds of companion plants (5\%). From their interactions with other farmers in their neighborhood, $50 \%$ of the respondents said that other farmers were interested in trying 3G-PPT on their farms.

Farmer ratings on effectiveness of the different cropping systems in controlling stemborers, FAW, and striga weed are presented in Figure 4. The ratings were 'very poor,' 'poor,' 'fair,' 'good,' and 'very good.' In 'very good' category, significantly higher percentage of farmers liked CS-PPT as compared to 3G-PPT in the management of stemborers, while 3G-PPT was preferred for control of FAW. The two PPTs did not differ significantly in control of striga weed and yield 


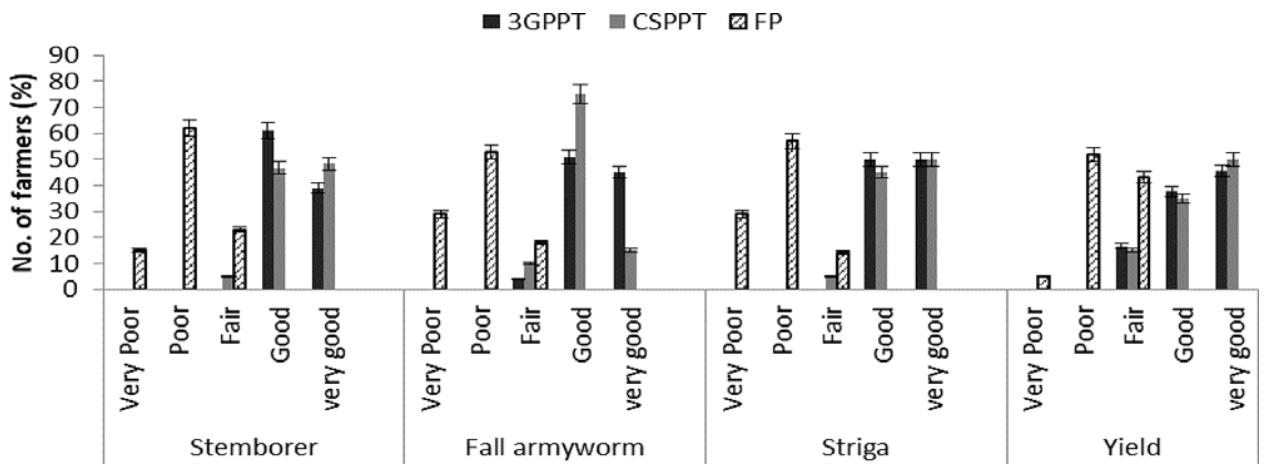

Figure 4. Farmer ratings of climate-smart push-pull technology (CS-PPT), third generation push-pull technology (3G-PPT) and farmer practice (FP) in control of stemborers, fall armyworm (FAW), striga weed, and grain yield improvement.

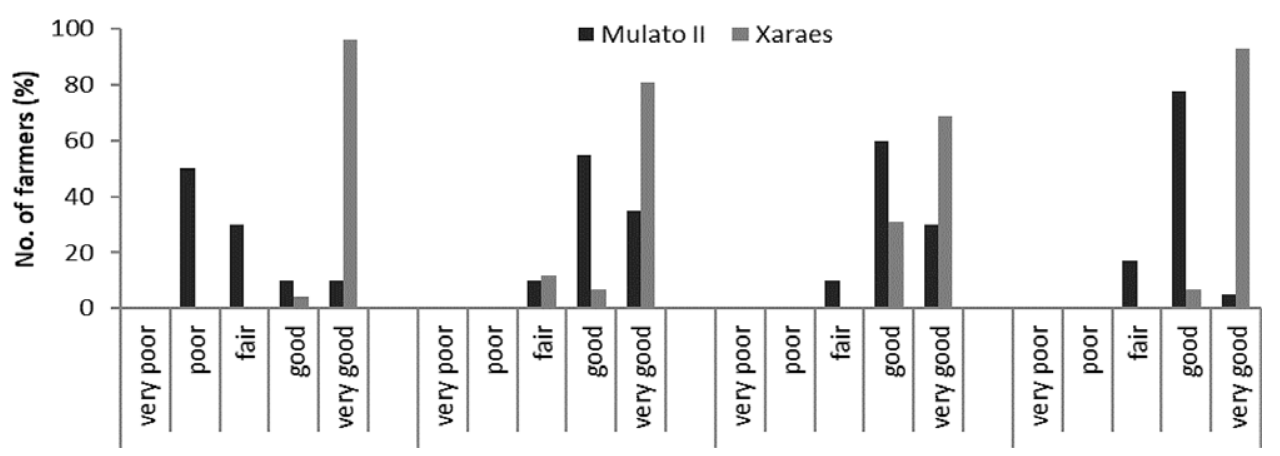

Figure 5. Farmer ratings of Brachiaria brizantha cv. Mulato II and B. brizantha cv Xaraes used trap plants in push-pull systems.

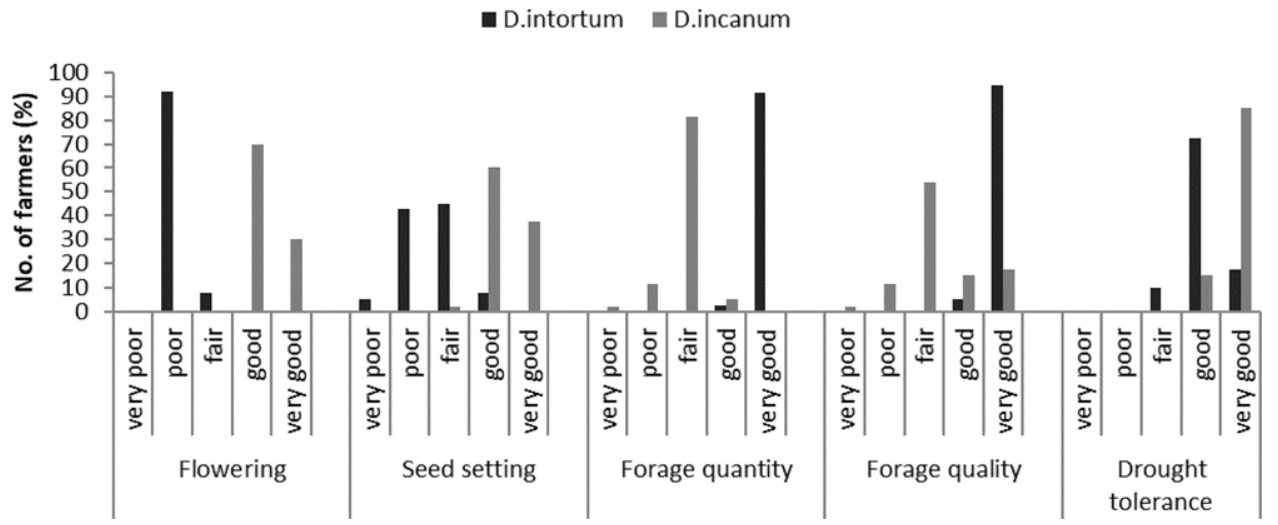

Figure 6. Farmer ratings of Desmodium intortum and D. incanum intercrops in Push-Pull systems.

performance. Farmer ratings of companion of plants on different traits of interest are presented in Figures 5 and 6. Xaraes was mostly rated as 'very good' in resistance to spider mites, quantity and quality of forage, and drought tolerance. Mulato II was mostly rated as 'good' in these qualities except for resistance to spider mites where it was mostly rated as 'poor'. D. incanum is mostly 
considered as 'good' to 'very good' in flowering, seed setting, 'very good' in drought tolerance, and 'fair' in forage quantity and quality. Greenleaf desmodium $D$. intortum on the other hand is mostly rated as 'very good' in forage quantity and quality, 'good' in drought tolerance, but 'poor' in flowering and seed setting.

\section{Discussion}

The impact of climate change on cereal production in Africa is projected to increase, posing a threat to the region's ability to feed its growing population. PPT technology was originally developed to help smallholder cereal-livestock farmers in the continent against a number of biotic and non-biotic production challenges. Our study revealed that an improved version of PPT, a 3G-PPT, based on recently identified companion plants, is better adapted to dry spells and is equally effective in reducing stemborers, striga, and FAW as compared to an earlier version CS-PPT. Improved yields in PPT systems as compared to FPs are attributed to the technology's cumulative impact including control of striga weed, stemborers, and FAW in PPT (Khan et al., 2008b; Midega et al., 2015a; Vanlauwe et al., 2008). In the current study, infestation by striga was low in CS-PPT and 3G-PPT plots compared to FP plots. This is consistent with previous study which show significantly lower infestation in fields intercropped with Desmodium species including D. incanum, demonstrating effective control of striga under field conditions (Midega et al., 2018). D. incanum is drought tolerant; hence, it guarantees continual striga seed bank depletion even when there is no cereal crop in the field (Midega et al., 2017). Moreover, it does not shed its leaves when exposed to severe drought stress conditions. This ensures consistency in the nitrogen fixation processes, production of root exudates that inhibit striga, and emission of leaf volatiles that repel cereal stemborers. Striga control by both D. intortum and D. incanum is due to the allelopathic effects by its non-volatile root exudates and benefits of increased availability of nitrogen and soil shading (Hooper et al., 2015; Khan et al., 2000, 2002; Tsanuo et al., 2003).

Farmer participatory research is essential in validating potential of agricultural products and technologies. In the present study, farmers rated the two PPT systems as equally beneficial in control of stemborers, FAW, striga, and with improved yields as compared to their own practices. Preference between CS-PPT and 3G-PPT, nonetheless, differs depending on farmer experience and trait preference of the companion plants. Farmers reported Mulato II as highly susceptible to spider mite Oligonychus trichardti, a serious pest of brachiaria despite having good biomass yield and tolerance to drought. Xaraes is a better alternative in areas such as Suba and Kisumu (Table 2) that experience frequent attacks of the mites that coincide with extended periods of dry and hot conditions favorable for the pest. Indeed, Xaraes demonstrated good resistance to spider mites, besides having good biomass yield, during laboratory screening. This is consistent with findings of previous experimental and farmer perception studies which show Mulato II as highly susceptible while Xaraes combines moderate resistance to the pest and high biomass yield (Cheruiyot et al., 2020, 2018a). One of the major challenges in adoption of the technology is shortage of inputs especially desmodium seed, which is expensive for the resource-constrained farmers (Khan et al., 2014). In our study, farmers preferred $D$. incanum for its ability to flower, produce seeds, and survive extended periods of drought although its biomass is lower than that of $D$. intortum. For this reason, farmers practicing 3G-PPT thus have the advantage of producing seeds for own use or sell to other farmers.

In conclusion, although that the 3G-PPT and CS-PPT deliver equal benefits for control of stemborers, striga and FAW, and yield improvement, 3G-PPT ranked as more resilient to climate stressors than CS-PPT. This is in spite of the fact the newly developed version, which was two seasons old by the time of this study, is compared with earlier established climate-smart PPT farms of mostly over 5 years. It is worth mentioning, nonetheless, that efficiency of PPT is incremental over time. For instance, the capability of desmodium to control striga and improve soil 
fertility increases continuously (Khan et al., 2008b; Vanlauwe et al., 2008). Thus, with time the 3GPPT can potentially be even more effective than CS-PPT although an economic evaluation will be of importance to disentangle this. Furthermore, 3G-PPT is based on companion crops that are more resilient to hot and dry conditions, which are increasing rapidly in prevalence with climate change. This will ensure up-scaling of the technology to benefit more farmers especially those experiencing these problems in drier regions. The study further shows, through farmer perception approach that 3G-PPT is acceptable to smallholder famers because $D$. incanum can produce seeds (Fig. S2), Xaraes is resistant to spider mites (Fig. S2) and can produce high quantity and quality fodder for their livestock while both crops are tolerant to longer drought conditions. Lastly, Xaraes and $D$. incanum most importantly possess key properties that make them suitable for control of lepidopterous pests and striga (Cheruiyot et al., 2018b; Midega et al., 2017). Studies are underway to determine underlying mechanisms of invasive FAW control by these new companion plants. This is vital in ensuring sustainability of the technology in the event of a new invasive pest and that new planting materials release volatiles and root chemicals that are effective in control of pests and parasitic weeds.

Supplementary material. For supplementary material for this article, please visit https://doi.org/10.1017/ S0014479721000260

Acknowledgements. The authors gratefully acknowledge the financial support for this research by European Union (Fall Armyworm IPM Project DCI-FOOD/2018/402-634). The following organizations and agencies provide financial assistance to icipe and to the Push-Pull Programme: UK's Foreign, Commonwealth \& Development Office (FCDO); the Swedish International Development Cooperation Agency (Sida); the Swiss Agency for Development and Cooperation (SDC); the Norwegian Agency for Development Cooperation (NORAD); Biovision foundation (Switzerland); Biotechnology and Biological Science Research Council (BBSRC) of UK; the Federal Democratic Republic of Ethiopia and the Government of the Republic of Kenya. The views expressed herein do not necessarily reflect the official opinion of the donors.

We appreciate field assistance provided by Dickens Nyagol, Isaac Onyango, Romanus Odhiambo, supported by a team of field technicians. The farmers who hosted our trials and participated in the survey are greatly acknowledged.

\section{References}

Baudron F., Zaman-Allah M.A., Chaipa, I., Chari, N. and Chinwada P. (2019). Understanding the factors influencing fall armyworm (Spodoptera frugiperda JE Smith) damage in African smallholder maize fields and quantifying its impact on yield. A case study in Eastern Zimbabwe. Crop Protection 120, 141-150.

Berner D.K., Kling J.G. and Singh B.B. (1995). Striga research and control. A perspective from Africa. Plant Disease 79, 652-660.

Birkett M.A., Chamberlain K., Khan Z.R., Pickett J.A., Toshova T., Wadhams L.J. and Woodcock, C.M. (2006). Electrophysiological responses of the lepidopterous stemborers Chilo partellus and Busseola fusca to volatiles from wild and cultivated host plants. Journal of Chemical Ecology 32, 475-487.

Calatayud P.A., Guénégo H., Ahuya P., Wanjoya A., Le Rü B., Silvain J.F. and Frérot B. (2008). Flight and oviposition behaviour of the African stem borer, Busseola fusca, on various host plant species. Entomologia Experimentalis et Applicata 129, 348-355.

Chamberlain K., Khan Z.R., Pickett J.A., Toshova T. and Wadhams L.J. (2006). Diel periodicity in the production of green leaf volatiles by wild and cultivated host plants of stemborer moths, Chilo partellus and Busseola fusca. Journal of Chemical Ecology 32, 565-577. https://doi.org/10.1007/s10886-005-9016-5

Cheruiyot D., Midega C.A.O., Pittchar J.O., Pickett J.A. and Khan Z.R. (2020). Farmers' perception and evaluation of brachiaria grass (Brachiaria spp.) genotypes for smallholder cereal-livestock production in East Africa. Agriculture 10, 1-13. https://doi.org/10.3390/agriculture10070268

Cheruiyot D., Midega C.A.O., Ueckermann E.A., Van den Berg J., Pickett J.A. and Khan Z.R. (2018a). Genotypic response of brachiaria (Urochloa spp.) to spider mite (Oligonychus trichardti) (Acari: Tetranychidae) and adaptability to different environments. Field Crop Research 225, 163-169. https://doi.org/10.1016/j.fcr.2018.06.011

Cheruiyot D., Midega C.A.O., Van den Berg J., Pickett J.A. and Khan Z.R. (2018b). Genotypic responses of brachiaria grass (Brachiaria spp.) accessions to drought stress. Journal of Agronomy 17, 136-146. https://doi.org/10.3923/ja.2018.136.146

Cheruiyot D., Midega C.A.O., Van den Berg J., Pickett J.A. and Khan Z.R. (2018c). Suitability of brachiaria grass as a trap crop for management of Chilo partellus. Entomologia Experimentalis et Applicata 166, 139-148. 
Chidawanyika F., Midega C.A., Bruce T.J., Duncan F., Pickett J.A. and Khan Z.R. (2014). Oviposition acceptance and larval development of Chilo partellus stemborers in drought stressed wild and cultivated grasses of East Africa. Entomologia Experimentalis et Applicata 151, 209-217.

Cook S.M., Khan Z.R. and Pickett J.A. (2006). The use of Push-Pull strategies in integrated pest management. Annual Review of Entomology 52, 375.

De Groote H. (2002). Maize yield losses from stemborers in Kenya. Internal Journal of Tropical Insect Science 22, 89-96.

De Groote H., Kimenju S.C., Munyua B., Palmas S., Kassie M. and Bruce A. (2020). Spread and impact of fall armyworm (Spodoptera frugiperda J.E. Smith) in maize production areas of Kenya. Agriculture, Ecosystems and Environment 292, 106804. https://doi.org/10.1016/j.agee.2019.106804

Ekpa O., Palacios-Rojas N., Kruseman G., Fogliano V. and Linnemann A.R. (2018). Sub-Saharan African maize-based foods: technological perspectives to increase the food and nutrition security impacts of maize breeding programmes. Global Food Security 17, 48-56.

Food and Agricultural Organization of the United Nations (FAO) (2016). Food balance sheets. FAO Stat. Databases Rome, Italy. Available online at http://www.fao.org/3/a-bo092e.pdf (accessed on 10 September 2020).

Goergen G., Kumar P.L., Sankung S.B., Togola A. and Tamò M. (2016). First report of outbreaks of the fall armyworm Spodoptera frugiperda (JE Smith)(Lepidoptera, Noctuidae), a new alien invasive pest in West and Central Africa. PLoS One 11, e0165632.

Hariprasanna K. and Rakshit S. (2016). Economic importance of sorghum. In The sorghum genome. Cham: Springer, pp. 1-25.

Hooper A.M., Caulfield J.C., Hao B., Pickett J.A., Midega C.A.O. and Khan Z.R. (2015). Isolation and identification of desmodium root exudates from drought tolerant species used as intercrops against Striga hermonthica. Phytochemistry 117, 380-387. https://doi.org/10.1016/j.phytochem.2015.06.026

Hooper A.M., Hassanali A., Chamberlain K., Khan Z. and Pickett J.A. (2009). New genetic opportunities from legume intercrops for controlling Striga spp. parasitic weeds. Pest Management Science: formerly Pesticide Science 65, 546-552.

Hooper A.M., Tsanuo M.K., Chamberlain K., Tittcomb K., Scholes J., Hassanali A., Khan Z.R. and Pickett J.A. (2010). Isoschaftoside, a C-glycosylflavonoid from Desmodium uncinatum root exudate, is an allelochemical against the development of Striga. Phytochemistry 71, 904-908.

International Center of Insect Physiology and Ecology (icipe) (2019). The 'Push-Pull' Farming System : Climate-smart, sustainable agriculture for Africa. ISBN:978-9966-063-26-7

Jordan W.R. and Sullivan C.Y. (1982). Reaction and resistance of grain sorghum to heat and drought. In Sorghum in the Eighties: Proceedings of the International Symposium on Sorghum. 27 November 1981, ICRISAT Center Patancheru, AP India. (Vol. 1, pp. 131-142). ICRISAT.

Kfir R., Overholt W.A., Khan Z.R. and Polaszek A. (2002). Biology and management of economically important lepidopteran cereal stemborers in Africa. Annual Review of Entomology 74, 701-731.

Khan Z., Midega C.A.O., Hooper A. and Pickett J. (2016). Push-Pull: chemical ecology-based Integrated Pest Management technology. Journal of Chemical Ecology 42, 689-697. https://doi.org/10.1007/s10886-016-0730-y

Khan Z.R., Ampong-Nyarko K., Chiliswa P., Hassanali A., Kimani S., Lwande W., Overholt W.A., Pickett J.A., Smart L.E. and Woodcock C.M. (1997). Intercropping increases parasitism of pests. Nature 388, 631-632. https://doi.org/10.1038/ 41681

Khan Z.R., Hassanali A., Overholt W., Khamis T.M., Hooper A.M., Pickett J.A., Wadhams L.J. and Woodcock C.M. (2002). Control of witchweed Striga hermonthica by intercropping with Desmodium spp., and the mechanism defined as allelopathic. Journal of Chemical Ecology 28, 1871-1885. https://doi.org/10.1023/A:1020525521180

Khan Z.R., Midega C.A.O., Amudavi D.M., Hassanali A. and Pickett J.A. (2008a). On-farm evaluation of the "Push-Pull" technology for the control of stemborers and striga weed on maize in western Kenya. Field Crops Research 106, 224-233. https://doi.org/10.1016/j.fcr.2007.12.002

Khan Z.R., Midega C.A.O., Bruce T.J.A., Hooper A.M. and Pickett J.A. (2010). Exploiting phytochemicals for developing a 'push-pull' crop protection strategy for cereal farmers in Africa. Journal of Experimental Botany 61, 4185-4196. https://doi. org/10.1093/jxb/erq229

Khan Z.R., Midega C.A.O., Pittchar J.O., Murage A.W., Birkett M.A., Bruce T.J.A. and Pickett J.A. (2014). Achieving food security for one million sub-Saharan African poor through Push-Pull innovation by 2020. Philosophical Transactions of Royal Society B: Biological Sciences 369, 20120284-20120284. https://doi.org/10.1098/rstb.2012.0284

Khan Z.R., Midega C.A.O., Wadhams L.J., Pickett J.A. and Mumuni A. (2007). Evaluation of Napier grass (Pennisetum purpureum) varieties for use as trap plants for the management of African stemborer (Busseola fusca) in a push-pull strategy. Entomologia Experimentalis et Applicata 124, 201-211. https://doi.org/10.1111/j.1570-7458.2007.00569.x

Khan Z.R., Pickett J., van den Berg J., Wadhams L. and Woodcock C. (2000). Exploiting chemical ecology and species diversity: stemborer and striga control for maize and sorghum in Africa. Pest Management Science 56, 957-962.

Khan Z.R., Pickett J.A., Hassanali A., Hooper A.M. and Midega C.A.O. (2008b). Desmodium species and associated biochemical traits for controlling Striga species: present and future prospects. Weed Research 48, 302-306. https://doi.org/10. 1111/j.1365-3180.2008.00641.x 
Khan Z.R., Pickett J.A., Wadhams L. and Muyekho F. (2001). Habitat management strategies for the control of cereal stemborers and striga in maize in Kenya. International Journal of Tropical Insect Sciences 21, 375-380. https://doi.org/10.1017/ S1742758400008481

Khan Z.R., Pittchar J.O., Midega C.A.O. and Pickett J.A. (2018). Push-Pull farming system controls fall armyworm: lessons from Africa. Outlooks in Pest Management 29, 220-224. https://doi.org/10.1564/v29 Oct 09

Maass B.L., Midega C.A.O., Mutimura M., Rahetlah V.B., Salgado P., Kabirizi J.M., Khan Z.R., Ghimire S.R. and Rao I.M. (2015). Homecoming of Brachiaria: Improved hybrids prove useful for African animal agriculture. East African Agricultural and Forestry Journal 81, 71-78. https://doi.org/10.1080/00128325.2015.1041263

Mbow C., Rosenzweig C., Barioni L.G., Benton T.G., Herrero M., Krishnapillai M., Liwenga E., Pradhan P., Rivera-Ferre M.G. and Sapkota T.B. (2019). Climate Change and Land: an IPCC Special Report on Climate Change, Desertification, Land Degradation, Sustainable Land Management, Food Security and Greenhouse Gas Fluxes in Terrestrial Ecosystems. IPCC. Food Security, 437-550. https://www.ipcc.ch/site/assets/uploads/2019/11/08_Chapter-5.pdf

Midega C.A.O., Bruce T.J.A., Pickett J.A. and Khan Z.R. (2015a). Ecological management of cereal stemborers in African smallholder agriculture through behavioural manipulation. Ecological Entomology 40, 70-81.

Midega C.A.O., Bruce T.J.A., Pickett J.A., Pittchar J.O., Murage A. and Khan Z.R. (2015b). Climate-adapted companion cropping increases agricultural productivity in East Africa. Field Crops Research 180, 118-125. https://doi.org/10.1016/j.fcr. 2015.05.022

Midega, C.A.O., Khan, Z.R., Amudavi, D.M., Pittchar, J. and Pickett, J.A. (2010). Integrated management of Striga hermonthica and cereal stemborers in finger millet (Eleusine coracana (L.) Gaertn.) through intercropping with Desmodium intortum. International Journal of Pest Management 56, 145-151. https://doi.org/10.1080/09670870903248843

Midega C.A.O., Khan Z.R., Pickett J.A. and Nylin S. (2011). Host plant selection behaviour of Chilo partellus and its implication for effectiveness of a trap crop. Entomologia Experimentalis et Applicata 138, 40-47. https://doi.org/10.1111/j.1570 7458.2010.01073.x

Midega C.A.O., Pittchar J.O., Pickett J.A., Hailu G.W. and Khan Z.R. (2018). A climate-adapted Push-Pull system effectively controls fall armyworm, Spodoptera frugiperda (J E Smith), in maize in East Africa. Crop Protection 105, 10-15. https://doi.org/10.1016/j.cropro.2017.11.003

Midega C.A.O., Wasonga C.J., Hooper A.M., Pickett J.A. and Khan Z.R. (2017). Drought-tolerant desmodium species effectively suppress parasitic striga weed and improve cereal grain yields in western Kenya. Crop Protection 98, 94101. https://doi.org/10.1016/j.cropro.2017.03.018

Murage A.W., Pittchar J.O., Midega C.A.O., Onyango C.O. and Khan Z.R. (2015). Gender specific perceptions and adoption of the climate-smart Push-Pull technology in eastern Africa. Crop Protection 76, 83-91. https://doi.org/10.1016/j. cropro.2015.06.014

Mutyambai D.M., Bass E., Luttermoser T., Poveda K., Midega C.A.O., Khan Z.R. and Kessler A. (2019). More than "Push" and "Pull"? Plant-Soil feedbacks of maize companion cropping increase chemical plant defenses against herbivores. Frontiers in Ecological Evolution 7, 217. doi: 10.3389/fevo.2019.00217

Mutyambai D.M., Bruce T.J.A., Van Den Berg J., Midega C.A.O., Pickett J.A. and Khan Z.R. (2016). An indirect defence trait mediated through egg-induced maize volatiles from neighbouring plants. PLoS One 11, 1-15. https://doi.org/10.1371/ journal.pone.0158744

Pageau K., Simier P., Le Bizec B., Robins R.J. and Fer A. (2003). Characterization of nitrogen relationships between Sorghum bicolor and the root-hemiparasitic angiosperm Striga hermonthica (Del.) Benth. using K15NO3 as isotopic tracer. Journal of Experimental Botany 789-799. https://doi.org/10.1093/jxb/erg081

Päts P. (1991). Activity of Chilo partellus (Lepidoptera: Pyralidae): eclosion, mating and oviposition time. Bulleting of Entomological Research 81, 93-96.

Pickett J.A. and Khan Z.R. (2016). Plant volatile-mediated signalling and its application in agriculture: successes and challenges. New Phytologist 212, 856-870. https://doi.org/10.1111/nph.14274

Pickett J.A., Woodcock C.M., Midega C.A.O. and Khan Z.R. (2014). Push-Pull farming systems. Current Opinion in Biotechnology 26, 125-132. https://doi.org/10.1016/j.copbio.2013.12.006

R Core Team (2020). R: A language and environment for statistical computing. R Foundation for Statistical Computing, Vienna, Austria. https://www.R-project.org/.

Stewart G.R., Press M.C., Graves J.D., Nour J.J. and Wylde A. (1991). A physiological characterization of the host parasite association between Sorghum bicolor and Striga hermonthica and its implication for Striga control, in: Combating Striga in Africa. Proceedings of the International Workshop Organised by IITA, ICRISAT and IDRC, 22-24 August 1988, Ibadan, Nigeria. pp. $48-54$.

Tsanuo M.K., Hassanali A., Hooper A.M., Khan Z., Kaberia F., Pickett J.A. and Wadhams L.J. (2003). Isoflavanones from the allelopathic aqueous root exudate of Desmodium uncinatum. Phytochemistry 64, 265-273.

Turlings T.C., Loughrin J.H., Mccall P.J., Röse U.S., Lewis W.J. and Tumlinson J.H. (1995). How caterpillar-damaged plants protect themselves by attracting parasitic wasps. Proceedings of the National Academy of Sciences 92, 4169-4174. 
Van den Berg J. (2006). Oviposition preference and larval survival of Chilo partellus (Lepidoptera: Pyralidae) on Napier grass (Pennisetum purpureum) trap crops. International Journal of Pest Management 52, 39-44. https://doi.org/10.1080/ 09670870600552653

Vanlauwe B., Kanampiu F., Odhiambo G.D., De Groote H., Wadhams L.J. and Khan Z.R. (2008). Integrated management of Striga hermonthica, stemborers, and declining soil fertility in western Kenya. Field Crops Research 107, 102-115. https:// doi.org/10.1016/j.fcr.2008.01.002

Whitney A.S. (1966). Nitrogen fixation by three tropical forage legumes and the utilization of legume-fixed nitrogen by their associated grasses. (Doctoral dissertation, Honolulu).

Ziska L.H., Blumenthal D.M., Runion G.B., Hunt E.R. and Diaz-Soltero H. (2011). Invasive species and climate change: an agronomic perspective. Climate Change 105, 13-42. https://doi.org/10.1007/s10584-010-9879-5

Cite this article: Cheruiyot D, Chidawanyika F, Midega CAO, Pittchar JO, Pickett JA, and Khan ZR (2021). Field evaluation of a new third generation push-pull technology for control of striga weed, stemborers, and fall armyworm in western Kenya. Experimental Agriculture 57, 301-315. https://doi.org/10.1017/S0014479721000260 